\title{
MUNICIPAL WASTE MANAGEMENT IN RURAL AREAS IN POLAND
}

\author{
Joanna Baran ${ }^{1}$, PhD \\ ${ }^{1}$ Warsaw University of Life Sciences (SGGW)
}

\begin{abstract}
The article concerns the municipal waste management system in rural areas in Poland. The first part of the research presents levels of generated municipal waste, morphological properties of waste and differing waste management fees. The second part uses a questionnaire to study 300 residents of rural areas in order to identify their opinion about the waste management system in place. Residents of rural areas are generally content with the system in place; approximately $2 / 3$ of them participate in selective waste collection and believe that the waste collection fee is appropriate.
\end{abstract}

Key words: rural areas, municipal waste management, recycling.

JEL code: Q53

\section{Introduction}

Poland generates approx. $200 \mathrm{~kg} /$ person less municipal waste than the EU average; on the other hand, approx. $50 \%$ of municipal waste is directed to landfill sites, which is a negative aspect in the context of pursuing a circular economy. Poland's accession to the EU resulted in a requirement to adapt Polish law to the applicable provisions of EU law, also with respect to waste management and environmental protection (Wysokinski et al., 2015). Poland has undertaken to take actions aimed at organizing waste management, in particular to limit the amount of municipal waste deposited in landfill sites and to decrease the percentage of biodegradable waste. It has also undertaken to significantly increase recycling rates of other waste fractions. To this end, changes in previous provisions of law concerning waste management were introduced (Czyzyk et al., 2012; Pietrzykowski, Wicki 2011).

On 1 January 2012, the Act on Maintaining Cleanliness and Order in Municipalities (Dz. U. 2011 No 152/897) came into effect. The amended Act has obligated municipalities to make extensive changes to the previous waste management system and, primarily, to claim waste ownership and reduce the amount of waste arriving at landfill sites. Municipalities are obligated-within specified deadlines-to reach appropriate levels of biodegradable waste reduction and to increase the recycling rate of other waste fractions (Baran, 2016). The amended Act has given municipalities numerous duties and tasks, the execution of which will enable the implementation of an appropriate municipal waste management system.

The aim of the article is to characterize the waste management system in rural areas and to identify the opinion of residents of rural municipalities concerning the system in place. The research intends to identify the levels of generated waste and its morphological composition, and the number of landfill sites in rural areas, and to make a comparison with indicators for cities. The research also identifies key issues of waste management in rural areas.

The research was conducted in two stages. In the first stage, sources included data published in Central Statistical Office databases, concerning waste management in rural areas in Poland. The second stage, in April-May 2017, consisted of a survey conducted among randomly selected residents of three rural municipalities from Mazowieckie Province. In total, 300 people were surveyed, including 165 women. The survey study concerned, inter alia, such things as the "waste tax" rate, frequency of waste collection, type of available waste receptacles, availability of information and environmental education. 


\section{Research results and discussion}

As part of the current waste management system in Poland, municipal self-governments are responsible for organizing the collection of municipal waste from real property owners, as well as for most of the aspects of waste management, including organizational and investment processes. The most important tasks of municipal self-governments include (Stys, Foks 2014):

- preparation and acceptance of rules for maintaining cleanliness and order, i.e. specification of, among other things, terms and conditions and the subject matter of contracts for entities operating municipal waste management businesses;

- specification of rates for managing municipal waste;

- provision of construction, maintenance and operation of owned, or shared with other municipalities or economic entities, facilities and equipment for recycling and neutralizing municipal waste, or provision of conditions for construction, maintenance and operation of facilities and equipment for recycling and neutralizing municipal waste by economic entities;

- preparing and conducting tender proceedings for collection and management of municipal waste.

Figure 1 shows the scheme of the organization of the municipal waste collection system in Poland.

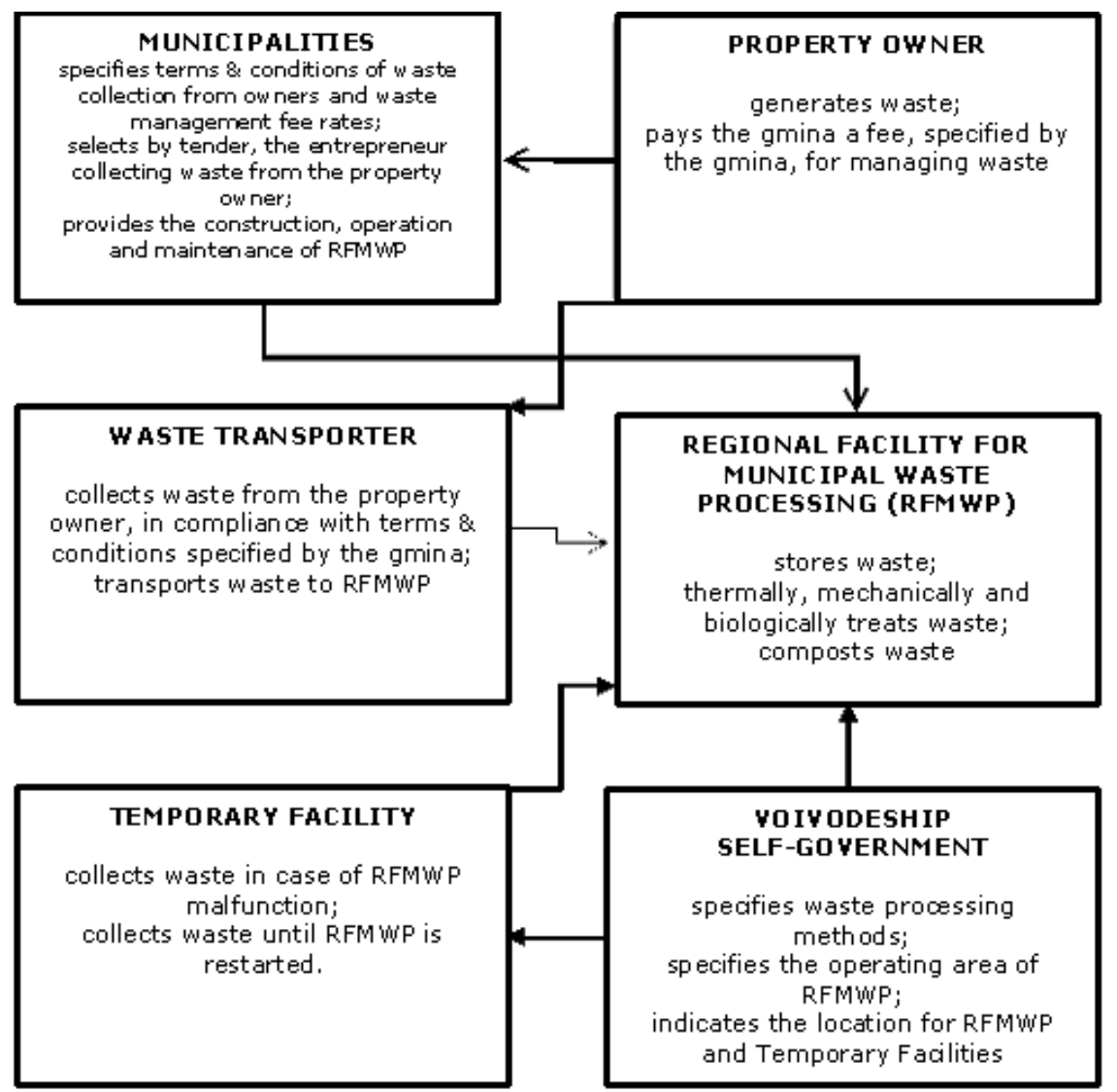

Source: Maciejczak, Baran, 2017

Fig. 1. Simplified organizational scheme of the municipal waste management system in Poland

Rural areas occupy about $93 \%$ of Poland and almost $40 \%$ of the population live in rural area; therefore, these areas cannot be marginalized in municipal waste management. Rural areas differ from urban areas in the field of waste generation and management (Baran, 2015). In rural areas in Poland, the generation of municipal waste is over three times lower than in urban areas (Figure 2). 
The rural community generated 2.3 million tons of municipal waste in 2016, which gives approx. $140 \mathrm{~kg}$ per 1 resident (in cities: $335 \mathrm{~kg}$ ). Compared to 2005, the amount of waste generated by the rural community increased (by $56 \%$ ); therefore, the amount of waste per 1 resident is also higher. The most waste per 1 rural resident was identified in Zachodniopomorskie and Lubuskie Provinces, the least in Swietokrzyskie, Lubelskie and Podkarpackie Provinces (Table 1).

In rural areas in 2016, 30 controlled municipal waste landfill sites have ceased operation, which means that 228 landfill sites remained operational in 31 XII 2016. Compared to 2005, the number of landfill sites decreased over threefold, and their area decreased nearly twofold (figure 3 ). Illegal landfill sites are a significant problem, with over 2.000 such sites in rural areas.

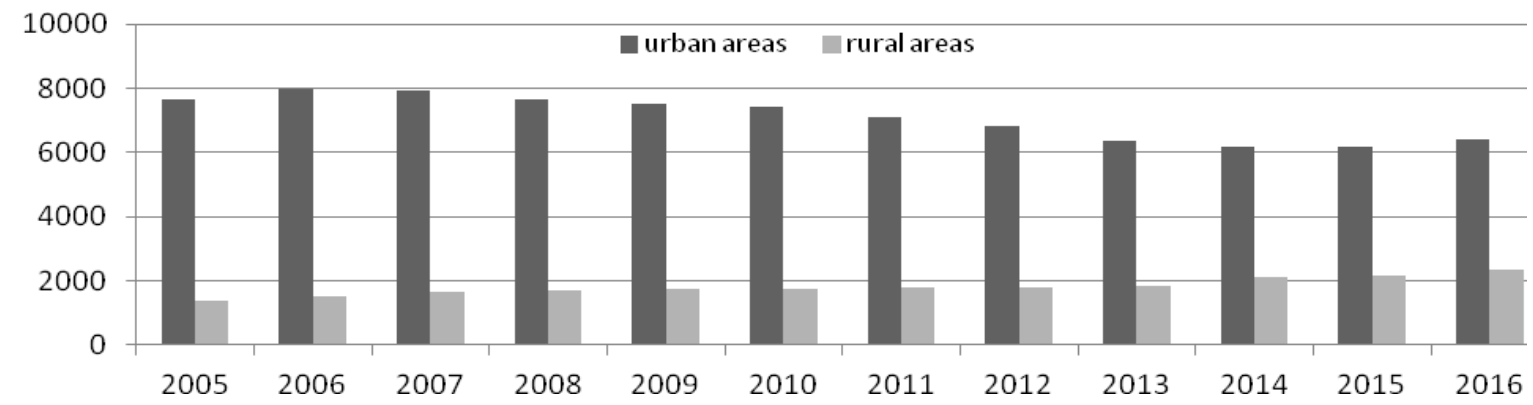

Source: author's calculations based on Municipal Infrastructure, Central Statistical Office, 2005-2016

Fig. 2. Mixed municipal waste (without selectively collected waste) collected in rural areas and urban areas in 2005-2016 (thous. t)

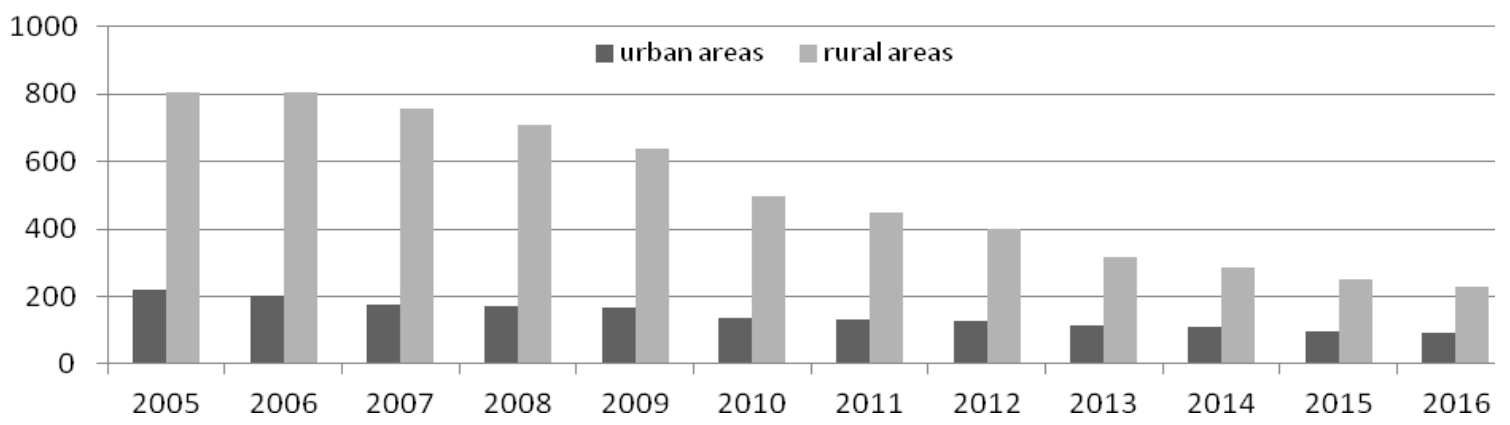

Source: author's calculations based on Municipal Infrastructure, Central Statistical Office, 2005-2016

Fig. 3. Controller landfill sites in rural areas and urban areas in 2005-2016

The morphological composition of waste from households in rural areas is dominated by organic waste, which constitutes nearly a half of municipal waste (Figure 4). Such waste can be divided into two main streams: the first is organic kitchen waste (food remains, vegetable and fruit peelings etc.); the second is green waste generated when maintaining areas around buildings (grass, leaves, branches, weeds etc.). Per year, an average resident of rural areas generates approx. $61 \mathrm{~kg}$ of organic kitchen waste and approx. $15 \mathrm{~kg}$ of garden waste (Czyzyk et al., 2015). The majority of organic waste (as much as $90 \%$ ) can be managed at the household. The bulk of biowaste is suitable for composting, while food remains are often used to feed animals. Municipalities must search for solutions encouraging household owners to select biodegradable fractions from the waste stream and equip the households with, e.g. compost bins. The next significant fraction in the morphological composition of waste from rural households is combustion waste, which constitutes approx. $28 \%$ of waste in winter. The next group of waste is waste suitable for recycling, including over $5 \%$ of paper and board, $7.5 \%$ of plastics, and $10 \%$ of glass. 
Morphological composition of waste from households varies depending on season (Figure 4). Pronounced seasonal changes can be seen in the percentage of combustion waste (more in winter, less in summer) and organic waste (more in summer, less in winter) in total waste.

winter

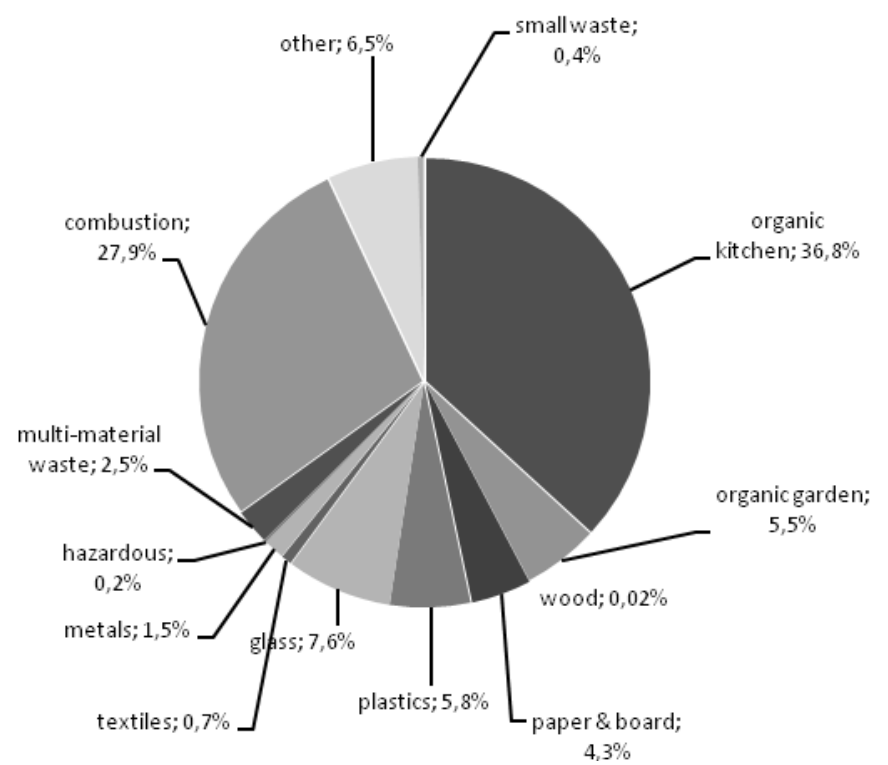

summer

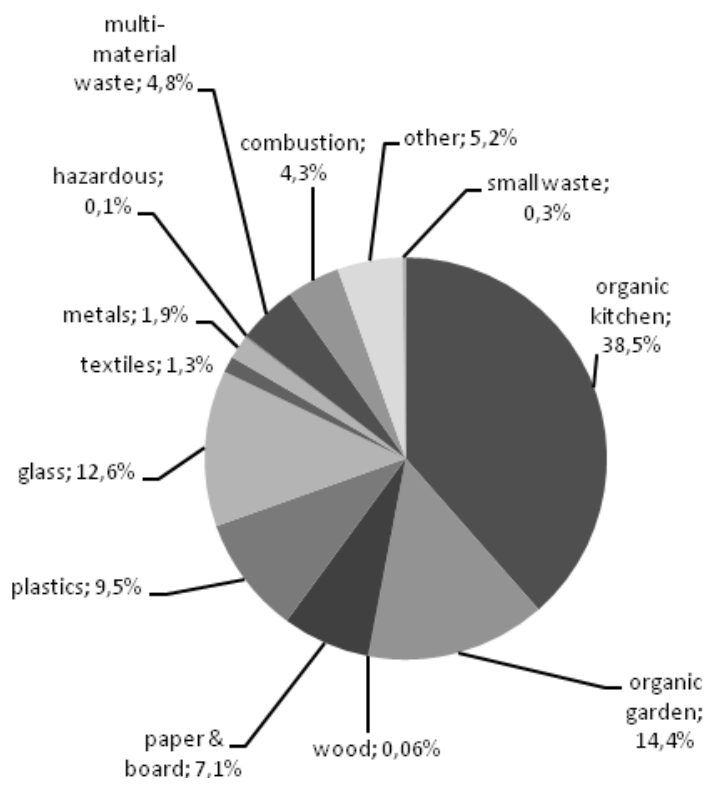

Source: author's calculations based on Czyzyk et al., 2015

Fig. 4. Share of individual material fractions in municipal wastes originating from households in rural areas in winter and summer

Municipal waste per 1 resident and rates of waste management fees in rural and urban areas in 2015

\begin{tabular}{|l|c|c|c|c|c|}
\hline \multirow{2}{*}{ Provinces } & \multirow{2}{*}{$\begin{array}{c}\text { Municipal } \\
\text { waste* per capita } \\
\text { in rural areas }\end{array}$} & \multicolumn{2}{c|}{$\begin{array}{c}\text { Rural municipalities } \\
\text { PLN/month/ resident }\end{array}$} & \multicolumn{2}{c|}{$\begin{array}{c}\text { Rural-urban municipalities } \\
\text { PLN/ month / resident }\end{array}$} \\
\cline { 3 - 6 } & $\begin{array}{c}\text { (kg) } \\
\text { selected } \\
\text { waste }\end{array}$ & $\begin{array}{c}\text { mixed waste } \\
\text { selected } \\
\text { waste }\end{array}$ & $\begin{array}{c}\text { mixed } \\
\text { waste }\end{array}$ \\
\hline Lower Silesia & 189.7 & 13.7 & 23.2 & 11.3 & 17.5 \\
\hline $\begin{array}{l}\text { Kuyavia- } \\
\text { Pomerania }\end{array}$ & 144.6 & 10.1 & 19.2 & 7.5 & 13 \\
\hline Lublin & 72.5 & 5 & 10.1 & 7.3 & 13.3 \\
\hline Lubusz & 209.5 & 8.9 & 15.3 & 11.2 & 20.4 \\
\hline Lodzkie & 121.3 & 6.6 & 12.5 & 7.8 & 13.9 \\
\hline Lesser Poland & 109.8 & 6.1 & 11.2 & 6.1 & 10.2 \\
\hline Masovia & 124.9 & 7 & 13.3 & 7.3 & 13.9 \\
\hline Opole & 179 & 9.6 & 17.8 & 10.3 & 17.8 \\
\hline Subcarpathia & 83.1 & 8 & 16.1 & 7.4 & 12.4 \\
\hline Podlasie & 116.3 & 7 & 12.6 & 7.3 & 13 \\
\hline Pomerania & 180.5 & 9.3 & 16 & 11 & 20 \\
\hline Silesia & 173.2 & 7.4 & 15.1 & 7.3 & 15.3 \\
\hline Swiętokrzyskie & 61 & 7 & 13 & 3.8 & 7.3 \\
\hline Warmia-Masuria & 141.5 & 8.9 & 12.4 & 8.3 & 12.1 \\
\hline Greater Poland & 1187.4 & 7.6 & 13.4 & 8.5 & 14.7 \\
\hline West Pomerania & 210.4 & 12.3 & 18.8 & 11.9 & 20.7 \\
\hline nexcludingaste & & & & & \\
\hline
\end{tabular}

* excluding waste collected separately

Source: Steinhoff-Wrzesniewska 2015; Czyzyk et al., 2015 
Waste management system should operate according to the waste management hierarchy. According to this hierarchy, actions concerning waste management should first consist of preventing the generation of waste, or limiting its amount. If waste is already generated, it should be prepared for reuse or subjected to the recycling process. Disposal consisting in long-term waste storage is relatively the simplest, but the least desirable method (Teodorowicz, 2013, p. 29; Michniewska, 2016, p. 22).

According to the waste management hierarchy, the primary tasks of municipalities, laid down in the provisions of the Act introduced in 2012, is the selective municipal waste collection "at the source." The majority of rural residents have declared their intention to sort waste, which is also connected with a lower fee. Fee variation was intended to encourage waste producers to sort waste. Experiences of other countries indicate, however, that the measured, actual sorting level is considerably lower than the one declared by residents. Therefore, we shouldn't confuse willingness to sort waste with the actual "recycling rate" (Dahlen, Lagerkvist, 2010).

It is worth mentioning that, for rural municipalities, the rate for both sorted and unsorted waste is lower than rates applicable in urban-rural municipalities (Table 1). Fees for unsorted waste were set by rural municipalities at a level approx. $100 \%$ higher than fees for sorted waste. Average municipal waste fees in municipalities of the following provinces: Lubelskie, Mazowieckie, Podkarpackie and Swiętokrzyskie were at a such low level, that there was a risk of not balancing the waste management system. Low rates for waste collection set by municipalities were probably connected with the expected social resistance with respect to paying the so-called "waste tax" (Malinowski, 2014; Golen, 2014; Gornicki, 2014; Steinhoff-Wrzesniewska, 2015).

The opinion research sample consisted of 300 residents of three rural municipalities. Among the surveyed, women were the majority $(55 \%) .45 \%$ of respondents are people with tertiary education, while $33 \%$ have secondary education (Table 2 ). The majority of respondents are people under 50 years of age who, after graduating, returned and settled in rural municipalities. The majority of people surveyed live in single-family homes.

Properties of the research sample (in \%)

Table 2

\begin{tabular}{|l|l|c|c|c|}
\hline \multicolumn{2}{|c|}{ Property } & Women & Men & Total \\
\hline \multirow{4}{*}{ Age } & Under 25 & 22 & 12 & 34 \\
\cline { 2 - 5 } & $25-50$ & 23 & 18 & 41 \\
\cline { 2 - 5 } & Over 50 & 10 & 15 & 25 \\
\cline { 2 - 5 } & Total & 55 & 45 & 100 \\
\hline \multirow{4}{*}{ Education } & Primary & 3 & 3 & 6 \\
\cline { 2 - 5 } & Vocational & 2 & 14 & 16 \\
\cline { 2 - 5 } & Secondary & 22 & 11 & 33 \\
\cline { 2 - 5 } & Tertiary & 28 & 17 & 45 \\
\hline & Single-family & 49 & 29 & 78 \\
\cline { 2 - 5 } & Multi-family & 6 & 16 & 22 \\
\cline { 2 - 5 } & Total & 55 & 45 & 100 \\
\hline
\end{tabular}

Source: author's research

The majority of people surveyed $(66 \%)$ declare that they sort municipal waste generated at their households and state that the main reason for undertaking this method of solid waste collection is the desire to care for the natural environment and the fact that the fees are lower when participating in selective collection (Figure 5). However, the respondents who declared that they collect only mixed waste at their households state that the reason for their decision is that 
sorting is burdensome, because it takes a long time and requires a lot of space for receptacles intended for various waste fractions. The respondents who don't sort waste justify their decision with the reason that participation in selective collection by individuals will not change anything ("sorting would be reasonable if everyone did it, and they did it earnestly").

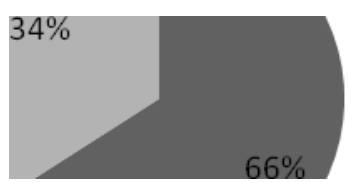

I sort waste

I don't sort waste

Source: author's research

Fig. 5. Respondents' answers concerning waste sorting

The interviewees were then asked to state their opinion about the frequency of waste collection and the type and number of receptacles provided by the waste collection company (Figure 6). Over a half of the interviewees believe that these two components of the system operate correctly. Nonetheless, approximately one third of the interviewees state that the waste collection frequency is insufficient, and the type and number of receptacles are inappropriate.
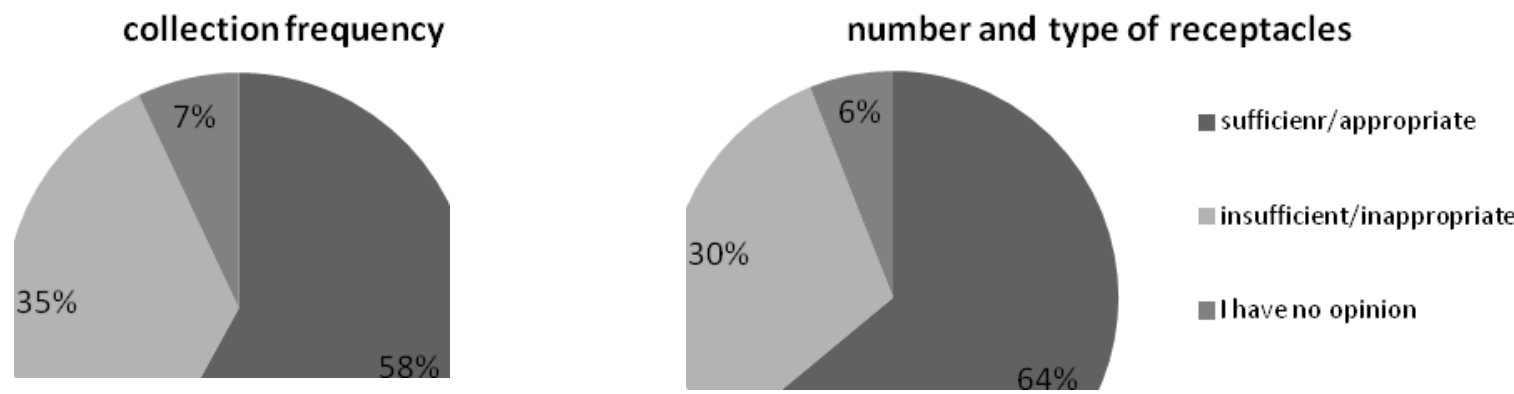

\section{Source: author's research}

Fig. 6. Interviewees' opinion on waste collection frequency and number and type of waste receptacles

$45 \%$ of interviewees believe that waste collection fees are appropriate. $29 \%$ of respondents state that the rate should be lower (Figure 7). Some interviewees emphasize that the difference between fees for different types of collection (sorted/unsorted) should be higher, which could encourage people to participate in selective collection. However, implementing a larger difference could result in the aforementioned phenomenon of declaring selective collection (for money-saving reasons) and not observing it at households.

The interviewees were also asked to indicate how their waste collection expenses have changed since the introduction of waste management system changes. $52 \%$ of respondents state that the costs have increased; $19 \%$ say that they remain on the same level; $6 \%$ state that they decreased, while $23 \%$ of interviewed people are unable to determine this. It should be, however, noted that, until the second half of 2013, residents were managing municipal waste themselves- 
some of them had contracts with waste collection companies, some deposited their waste in local landfill sites, while some burned the majority of generated waste in furnaces. Therefore, the increase in waste collection expenses should have been expected.

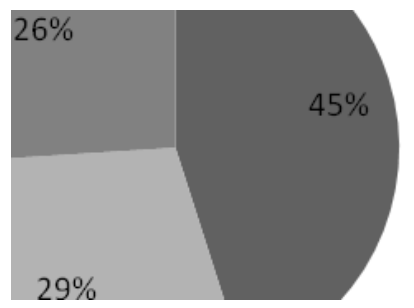

fee rates appropriate

free rates inappropriate

I have no opinion

\section{Source: author's research}

\section{Fig. 7. Interviewees' opinion on waste collection fee rates}

The comparison of cost information with information obtained in the question about satisfaction with changes introduced in 2013 indicates that the financial factor is not a key factor determining the satisfaction with waste management system operation-19\% of respondents, despite stating that their expenses increased, are satisfied with waste management system changes.

The interviewees were also asked about their opinion on environmental education conducted by the municipality office. Study results in this aspect can be seen as unsettling, because only $44 \%$ of respondents state that the municipality office has been conducting environmental education and, therefore, performed its statutory duty. Over $50 \%$ of interviewees state that there were no environmental education campaigns ( $22 \%$ of choices), or that they didn't know about such initiatives (34\% of choices). It should be stated that proper approach to waste largely depends on appropriate education in this respect.

\section{Conclusions, proposals, recommendations}

The analyses conducted in this article can be used to draw the following conclusions.

1) Correct organization of municipal waste management is a very complex task. Poland had to adjust to EU directives and accession-related obligations with respect to waste management, which included, in particular: reduction of biodegradable waste storage, increased recycling rates, adjusting municipal waste landfill sites to EU standards. Waste management policy in Poland has been a subject of dynamic changes since 2012. Municipalities were given the basic duties with respect to waste management. All municipality residents should fall under a statutory, organized municipal waste collection system.

2) Even though rural areas in Poland generate approximately three times less municipal waste, the majority of collected waste is deposited in landfill sites. Rural areas have over 2.5 times more controlled and uncontrolled landfill sites than in cities.

3) Main problems of rural areas include: aversion of residents to waste sorting, lack of discipline for observing selective waste collection and pollution of selectively collected waste, helplessness of municipalities in battling illegal waste landfill sites, burning waste in households, high transport costs (e.g. due to a colonial nature of development), lack of money for waste management infrastructure, ineffectiveness of conducted educational campaigns. 
4) Despite the fact that residents of rural municipalities mainly declare satisfaction with the waste management system in place, we can assume that the new Act on Waste did not bring the expected results with respect to both the reduction of illegally stored waste management and the creation of modern waste processing facilities, mainly incinerators. The primary task standing in front of rural municipalities is therefore a correct organization of selective collection and processing of the organic fraction of municipal waste, as well as educational campaigns, which will increase the environmental consciousness of the residents and encourage them to participate in correct waste management.

\section{Bibliography}

1. Baran, J. (2015). Regional Differentiation of Financial Support from the European Union and Its Impact on Agricultural Efficiency in Poland; Economic Science for Rural Development; Issue: 38; Jelgava, Latvia, pp. 227-238

2. Baran, J. (2016). Globalization Processes in Polish Food Industry; Economic Science for Rural Development; Issue: 42; Jelgava, Latvia, pp. 200-206.

3. Czyzyk, F., Strzelczyk, M., Steinhoff-Wrzesniewska, A., Paszkiewicz - Jasinska, A., Majewska, P., Godzwon, J., Rajmund, A., Helis, M. (2015). Gospodarka opadami komunalnymi na obszarach wiejskich (Municipal Waste Management in Rural Areas), Wroclaw, p. 5.

4. Czyzyk, F., Strzelczyk, M., Steinhoff-Wrzesniewska, A., Rajmund, A., Godzwon, J., Majewska, P. (2012). System i zasady gospodarowania odpadami komunalnymi w gminie, w swietle nowych regulacji prawnych (The System and Principles of Municipal Waste Management in Municipalities, the Latest Legal Regulations, Wroclaw, pp. 1-49.

5. Dahlen, L., Lagerkvist, A. (2010). Pas as you throw. Strengths and Weakness of Weight-based Billing in Household Waste Collection Systems in Sweden. Waste Management. Vol.30, pp. 23-32.

6. Golen, M. (2014). Problemy ksztaltowania przez gminy oplat za gospodarowanie odpadami komunalnymi w swietle nowelizacji ustawy o utrzymaniu czystosci i porzadku w gminach (Municipal Waste Charges Set by Municipal Authorities in the light of the Amendment to the Act on the Maintenance of Cleanliness and Order in Municipalities). Studia i Prace Kolegium Zarzadzania i Finansow, vol. 138, pp. 125-141.

7. Gornick, E. (2014). Wpływ stawki opłaty za zagospodarowanie odpadow komunalnych na budzet gminy. Studia i Prace Kolegium Zarzadzania i Finansów. vol. 138, pp. 143-167.

8. Maciejczak, M., Baran, J. (2017). Economic Issues of Municipal Solid Waste Management: the Case of Poland, [in] Municipal Solid Waste: Management Strategies, Challenges and Future Directions, Nikolaos Tzortzakis (ed.). New York: Nova Science Publishers, pp. 19-46.

9. Malinowski, M. (2014). Analiza kosztow zbierania i transportu zmieszanych odpadow komunalnych. Infrastruktura i ekologia terenow wiejskich (Transport and Collection Costs Analysis of Mixed Municipal Solid Waste). Infrastructure and Ecology of Rural Areas. PAN. No IV/2/2014, Krakow, pp. 1179-1191.

10. Municipal Infrastructure, Central Statistical Office, 2005-2016.

11. Michniewska, K. (2016). The Role of the Sharing Economy in Achieving the Environmental Objectives of the European Union - New Business Models in Closing of the Loop of the Supply Chain (SSC/CLSC), Journal of Reverse Logistics 1/2016 (2), pp. 20-28.

12. Pietrzykowski, R., Wicki, L. (2011). Regional Differentiation in Uptaking the CAP Funds on Agrienvironmental Programmes in Poland. Economic Science for Rural Development, 26, 149-162.

13. Steinhoff-Wrzesniewska, A. (2015). The Preparing Communities at Rural Areas for Waste Management in the Light of New Regulations. Archives of Waste Management and Environmental Protection, vol. 17, 2, pp. 49-58.

14. Stys, T., Foks, R. (2014). Rynek gospodarowania odpadami komunalnymi w Polsce. Perspektywa 2030 (Municipal Waste Management Market in Poland. Perspective 2030, Instytut Sobieskiego, Warsaw, p. 15.

15. Teodorowicz, H. (2013). Gospodarka odpadami w przedsiebiorstwie - praktyczny poradnik (Waste Management in the Enterprise a Practical Guide), Warsaw, p. 29.

16. Wysokinski, M.; Baran, J.; Florkowski, W. J.(2015). Concentration of Milk Production in Poland, Economic Science for Rural Development, Issue: 37, Jelgava, Latvia, p.93. 